\title{
8. Crunch-time for the University of Papua New Guinea
}

\section{ABSTRACI}

After a promising start as the place where many of the country's future leaders were educated, the University of Papua New Guinea is now a shadow of its former self. With minimal international support and destructive government policies ranking tertiary education of little importance for development, UPNG now operates on a budget totally inadequate to run a contemporary university. The minimal coverage of UPNG's decline in the national media is reflected in a poorly run journalism programme which has had a stop-start history. By comparison, the University of the South Pacific thrives and its management set targets to raise the proportion of people from member countries who attend tertiary education. International support, financial as well as supervisory, continues to make a major contribution to USP's operations. During major crises in Fiji, where USP's main campus is located, journalism students at the university have performed exemplary roles. Even the controversies which repeatedly surface about the programme indicate its continuing importance at USP. This essay argues that only the formation of a substantial consortium, with international donors joining a PNG government committed to a dramatic reversal of policy, can rescue what began as the country's premier tertiary institution. The demand for skilled and managerial labour in the South Pacific's second largest country, by population, requires a revitalised UPNG which could in turn lead a major reform of tertiary education and indeed all education.

Keywords: international aid, reactionary ruralism, tertiary education, University of Papua New Guinea; University of the South Pacific

\section{SCOTT MACWILLIAM}

ANU's College of Asia and the Pacific, Canberra

7 HE ONCE promising University of Papua New Guinea, home to the first journalism school in the Pacific (Robie, 1999, 2004), is in nearterminal decline. By comparison, the University of the South Pacific 
is thriving. One receives almost no international assistance, the other is the focus of bilateral and multilateral efforts, including the provision of tens of millions of US dollar equivalents, to expand and upgrade its presence in the South Pacific. USP is constantly the subject of media coverage, favourable and unfavourable, while UPNG's parlous state is rarely examined in that country's press, radio and television. Only student unrest, robberies and the occasional opinion piece by an expatriate academic which warns of the decay at UPNG makes it into PNG's media. There are continuous complaints in Letters to the Editor columns and similar outlets about the corruption, misuse of funds, low standards, lack of resources and myriad other grievances against the country's educational institutions in general.

While the domestic politics of PNG and the member countries of USP have played an important part in each university's condition, the focus of this essay is on the contribution - or lack of it - made by other national and international agencies. This focus is given by the author's conclusion that only a major international effort combined with a complete U-turn in national government policies can rescue UPNG, and tertiary education in general in Papua Guinea. The people of the second most populous country in the south-west Pacific deserve better and the entire region will benefit from their education to the highest standards which can be achieved.

\section{Good and bad aid}

Since the early 1990s at least, it has been commonplace to assess the consequences of international multilateral and bilateral aid in such terms as meeting 'good' governance criteria, providing for accountability, transparency and openness (Larmour 1998, pp. 1-20). Subsequently criteria including effectiveness have been used (Commonwealth of Australia, 2011). As well, against the attacks from a vocal and influential anti-aid lobby, aid has been evaluated favourably in terms of whether it 'really works' (Riddell, 2014). The sub-text of all assessments, while rarely if ever stated, is whether aid advances capitalism, more commonly thought of as profits, and meets particular welfare criteria.

Once the underlying purpose of aid, whether in meeting the politicalsecurity, law and order conditions for accumulation or making productive that which has become unproductive or under-productive, is acknowledged, it becomes possible to differentiate between good and bad aid. Because labour 
is the starting point of capital, the premise of and prerequisite for accumulation, good aid advances accumulation. In the case of education good aid facilitates training of a labour force which meets present and future, domestic and international markets. Bad aid, however effective it may be in meeting other objectives, including slowing population movement to urban areas and trapping people in rural soaks of unemployed and underemployed does little to extend and enlarge the process of accumulation. Bad aid is against development (Cowen \& Shenton, 1996; MacWilliam, 2013). Bad aid may also do nothing for the welfare of a country's population.

\section{Comparing the trajectories of USP and UPNG}

The establishment and subsequent operations of the two most important universities in the South Pacific, the regional University of the South Pacific (USP) and the national University of Papua New Guinea (UPNG), provide the basis for a comparative account of both good and bad aid. Both universities were founded at the end of colonial rule in the region, but have since followed different trajectories. Over the forty years, USP has become well established. By comparison, UPNG has declined as a tertiary institution to the point where the university may not recover unless urgent steps are taken to rebuild and expand it. In important respects, UPNG has followed the path described in the late 1990s by ANU academic Ron May for the country as a whole, as passing from 'promise to crisis' (May, 1998). However, since May wrote, as Papua New Guinea's (PNG's) economy has grown largely as an effect of a resources boom, UPNG's crisis has deepened.

While domestic conditions in the member countries, including Fiji where there has been a series of political crises since the first 1987 coup, have adversely affected the University of the South Pacific, continuing international support has considerably mitigated these adverse factors. This support has not only provided finance, when contributions from member countries have been less than anticipated, but has been extremely important for providing up-graded facilities. USP has continued international recruitment of staff, albeit sometimes with less success than the university's management would prefer, with funds provided by donors assisting wage and salary supplementation. This university's continued success as a tertiary institution with a broad international support has been important to the production of skilled and managerial labour power for member countries and wider labour markets, including in Australia and New Zealand. 
The international stance toward UPNG has differed and contributed significantly to the decline of the university, and tertiary education more generally in the country. Unlike USP where international support has mitigated the deleterious effects of domestic crises in member countries, for UPNG multilateral and bilateral institutions have supported the priorities of national governments. When these priorities have driven reductions in the financial support to education in general, tertiary education and UPNG in particular, the advice given by the World Bank, AusAID and other external institutions has only strengthened the directions taken by national governments.

This unity of objective, between domestic, other national and international institutions occurs because in political-ideological terms, the priorities of PNG governments as well as the policy stance favoured by international institutions continue to stem from a reactionary ruralism (described below). The position has primarily stressed a need for education at all levels that purportedly fits the bulk of the country's citizens for continued rural village life. As changes worldwide have shifted populations from rural to urban areas, with some estimates suggesting that in the early 21 st century for the first time over half the human population lived in cities and towns, education planning in Papua New Guinea has been instrumental in keeping attention on the countryside.

To fit the ideology of reactionary ruralism; since soon after Independence tertiary education which could provide the skills for urban manufacturing and service industries, as well as highly trained state employment, has been downgraded in importance. Perversely, even when effective, aid has 'delivered (the) results' of assisting in the destruction of whatever early promise UPNG had.

While a similar view which gave primacy to rural existence has driven aspects of government policy since Independence in a number of other South Pacific countries, it has not had the same damaging effects at USP as at UPNG. Although there are particular reasons why this is the case in each of the USP's member countries, they cannot be pursued in sufficient detail in this paper. To cite one example by way of illustration, in the case of Fiji, Indo-Fijian educational ambitions and achievements ensured a greater focus upon tertiary education, and USP, from its establishment. This in turn forced the ethnic Fijian, itaukei, elite to regard success at university as critical, with the attendant emphasis upon scholarships with allocation skewed to favour ethnic Fijian students. While "keeping itaukei down on the farm' remained one dimension of colonial and post-Independence state policy, another central aspect was 
'FAILED' STATES AND THE ENVIRONMENT

affirmative action for ethnic Fijians, which included strengthened support for scholarships to attend educational institutions, in this case USP (Ratuva 2013).

\section{Beginnings-Late colonial origins}

Both universities were constructed at the end of the colonial era, one as a regional institution, the other as PNG's premier tertiary institution. Each was intended to educate and train skilled and managerial labour, as well as produce the intellectual elite in countries where the bulk of the population lived in rural areas, occupying smallholdings. By the early 1960s opinion had shifted against the previous emphasis upon primary (Smith, 1985, p. 53) and secondary education. There was 'open espousal of higher education as a priority task' (University of Papua New Guinea, 1986, p. 1).

The growing demand for tertiary education came from a generation in the process of displacing the earlier commercial and political indigenous elite. The former's ambitions became more and more apparent as Independence approached. Increased Australian government funding, as well as the revenues generated by the massive Panguna mine on Bougainville enlarged the space in PNG's political economy which the younger generation of indigenous leaders would fill. A recent assessment of the outcomes which followed the establishment of two tertiary institutions, including UPNG, in the Australian colony has concluded that 'this quick and large investment in advanced education was remarkably successful' (Garnaut \& Namaliu, 2010, p. 7).

Soon after UPNG's foundation, tensions which had underpinned discussions in the Australian government and responsible departments were transferred to PNG. Simultaneous with these changes, Papua New Guineans moving to towns for wage work and other employment began to raise concerns about unemployed living in slums on the edge of urban centres. '(B)y the late 1960s employment for primary school leavers was no longer so readily available' even as secondary and tertiary educated indigenes initially filled public service and other white collar positions. Just a few years later, prior to Independence, "(e)ducated unemployment" and the social problems of "qualification escalation" began to be seen as a significant matter for concern in urban centres' (Smith, 1985, p. 61; Conroy, 1976). A tussle which continues commenced about the appropriateness of relatively expensive expenditure on tertiary education, and the perceived need among planners and academics to keep populations in rural areas, 'down on the farm'. The extent of urban 
unemployment was further exacerbated by the official antipathy toward all forms of import substituting industrialisation, which still remains. Instead indigenes and their advisers, in official reports and policy documents, stressed the romantic and other attributes of village life (Garnaut, 1981, pp. 161-162).

At the same time as the seeds of future policy to restrain urban migration and promote rural areas, to soak up the increasing relative surplus population, were germinating, village life was also subject to unrest and growing unemployment. Squatters were marching on to plantations, most prominently on the Gazelle Peninsula. So-called tribal fighting was extensive in the Highlands, driven primarily by land shortages with the most fertile land farmed by an older generation, leaving little available for subsequent generations (Government of Papua New Guinea, 1973; Wilson \& Evans, 1975; Anderson, 1977). Expatriate plantation owners, desperate to sell their holdings intact as going operations, were pressing the colonial administration to establish sources of funds to allow indigenous bourgeois and would-be bourgeois to purchase these properties.

While similar demographic and political-economic trends were appearing in other South Pacific countries as these became independent nation-states, USP continued as a producer of skilled and managerial workers, and national elites. USP, as a regional university with eleven original member South Pacific countries, now twelve, had been established in 1968, two years after UPNG. (Consideration is now being given to extend membership, to include a further three countries, one of which is Papua New Guinea.) Both universities were initially funded directly by the relevant colonial and regional powers, UPNG by Australia and USP by the United Kingdom, New Zealand and Australia. While the basis for UPNG's funding changed with Papua New Guinea's independence in 1975, USP has continued to receive substantial amounts of direct international aid, as outlined below.

\section{Post-Independence changes: Growth and decay}

\section{University of the South Pacific}

USP has continued to receive substantial amounts of direct international aid. In 1979, when there were over 1700 full and part-time students, the UK and Australian governments provided approximately one half of that year's income. By 1987, with New Zealand supplanting the UK as a direct source of income, according to the 1988 Report to Council, both proximate countries 


\section{‘FAILED’ STATES AND THE ENVIRONMENT}

provided a total of nearly FJD 1 million for staffing purposes. Ten years later, the 1997 Report contained a statement from Vice-Chancellor Esekia Solofa on a new building programme, of lecture theatres, tutorial rooms and computer laboratories made possible by funding from AusAID and the Japanese government which would double capacity (USP Vice-Chancellor's Report to Council, 1997).

At the end of the 1990s, with student numbers of more than 5,000, overseas aid on top of the funds for special projects exceeded FJD three million. By 2000 , even as aid from donor countries declined dramatically from the previous year, no less than seven countries had a direct financial stake in how USP operated. France, Canada and Taiwan were donor countries, on top of the earlier Australia, Japan, NZ and UK. As well multilateral agencies and private foundations had joined the list of donors. Even in one of USP's worst years for international financing, aid funds totalled almost FJD 10 million.

USP continues to be sustained by the South Pacific Partnership between Australia and the university. In 2010-2012, the financial assistance amounted to AUD 24 million. AUD18.35 was for the Strategic Plan, with the remainder allocated for a range of small projects, including internet infrastructure and scholarships. Additional funds were provided by Australia for the Pacific Islands Centre for Public Administration at USP, to improve public sector workforce planning, management and skills. The partnership has recently been renewed to cover USP's 2013-2018 Strategic Plan, with a further major increase in funding, in excess of AUD 40 million.

In June 2012 the Asian Development Bank (ADB) and USP signed the first agreement for a US\$19 million loan to assist the University upgrade its regional campuses and improve access to distance as well as e-learning. The agreement was a first for the ADB and USP, for the former in providing a highly concessional loan to a regional institution and for USP its initial development loan from the Bank. By 2013 USP had almost 25,000 students enrolled with campuses of varying capacities in all member countries. Consultancy, research and other funds acquired by staff have made possible the construction of an approximately FJD three million 'business' building for lectures, seminars and offices (Personal communication, 2014).

The Japanese government recently provided a further special grant of approximately FJD 40 million for the construction of an IT building, with offices, lecture rooms and computer facilities. USP's budget meets the on- 
going operating costs of approximately FJD 2-3 million for this building and equipment (Personal Communication, 2014). The main Laucala campus has WiFi connectivity for students and staff: on a recent visit, the large staff and student dining area was populated with students using notebooks and other electronic equipment to access international and domestic sites. As well as this private equipment, students also have access to the internet through computers located in the library and a range of teaching spaces, so individualisation is not the only means of access.

Financial and other international support for USP will amount to FJD 56 million in 2014, and is expected to rise to FJD 80 million in 2018. (These figures do not include member country contributions of almost FJD 48 million each year of the Plan.) Development assistance from countries and other donors including private foundations comprises just over 30 percent of total USP income for 2014, anticipated to rise to 37 percent by 2018 (USP, 20132018, p. 41).

Despite the already rapid growth, and with education of varying qualities, especially at the regional centres and via the overly ambitious extension of the online mode, USP's management has even grander plans. These include being central to a major increase in the proportion of people from the region who attend tertiary education (USP, 2010-2012, p. 2). Important for USP's position as the premier university in the South Pacific are the continuing scrutiny of its operations by international donors, forms of external assessment of courses and subjects offered, and recruitment of staff trained at universities outside the region. While working conditions, including personal safety, reduced comparability of wages and salaries, and major increases in teaching loads continue to affect USP's capacity to recruit internationally, the decline has not been as dramatic as in most areas of UPNG. USP is also engaging in an international drive to attract scholars, in part by increasing the numbers of professorial and research appointments (USP, 2013-2018, pp. 32-33). USP also maintained sufficient accreditation standards so that many graduates could gain employment in Australia, New Zealand and other industrial countries, often providing remittances to their places of origin.

Whatever unfavourable comparative assessments can be made of USP with universities in industrial countries, there is no doubt that when evaluated alongside UPNG, the latter is not in the same league as a producer of skilled and managerial labour power. This account now turns to the decay of 
'FAILED' STATES AND THE ENVIRONMENT

UPNG from the heyday of the late 1970s and early 1980s, before providing an explanation for the university's current condition.

\section{University of Papua New Guinea}

Until the mid-1980s, UPNG continued on an upward trajectory, producing skilled workers and members of the political-commercial elite. Facilities continued to be upgraded as administrative buildings, classrooms and student accommodation were completed at the main campus and at other centres, including Goroka Teachers College, now the University of Goroka. The UPNG computer network was launched in 1983. The library holdings expanded rapidly, and an archives collection commenced so that the facility was soon exceptional and the capacity of cataloguers to keep up with new purchases was often stretched. External assessments of programmes and courses continued to occur, and international recruitment as well as exchanges of staff with USP and other universities assisted to maintain the quality of teaching even as student numbers increased. The favourable exchange rate of the PNG kina by comparison with other currencies, including the Australian dollar, helped staff recruitment as well as equipment purchases. There were some signs that the UPNG budget was under stress, including in the lack of new buildings and extensions to what existed as required by the increased student numbers. Nevertheless the rapid decline which was to occur from the late 1980s and early 1990 s was not foreseen.

By 2010, when the most recent Review of PNG Universities was conducted, UPNG was in a parlous state. Although self-regarded as the country's main university with a mission to be 'the premier University of the Pacific making available quality education, research and services to Papua New Guinea and the Pacific', these lofty ambitions are all that remains for the institution. Even the official website, on which this mission statement appeared was last updated in March 2007. The site has now been closed.(www.upng.ac.pg/cgisys/suspended_page.shtml Accessed on 29 August 2014). More generally as the Review's authors, (Australian academic Ross Garnaut, and former UPNG academic as well as Prime Minister [Sir] Rabbie Namaliu) concluded regarding the country's universities:

Together the Papua New Guinea universities provide for a number of students that is small by any international standards relative to the national population and to the demand for professional and technical skills. There is a pressing problem of quantity, reinforced by the wide- 
spread and powerful demands by parents for more university places. Regrettably, we see an even more pressing problem with quality of the educational experience. (Garnaut \& Namaliu, 2010, p. 12].

Or, as the National Higher Education Plan III for 2010-2040 puts it in more grandiose terms: 'Higher education's enduring struggle to find its authenticity in the national development framework spans two decades' (Government of Papua New Guinea, 2010(b), p.12). With the possible exception of a handful of teaching areas which receive external support, and were noted as exceptional by the PNG Universities Review, there are few enterprising, innovative or entrepreneurial possibilities for the remainder of UPNG. Not only are buildings in need of repair and maintenance, teaching areas are grossly inadequate, and the library is antiquated in its holdings. Much of the student accommodation is in a near-slum state. Many staff are under-qualified, teaching excessive loads with little provision for up-grading qualifications or carrying out original research. There is negligible computer access and the internet is generally not functioning or at best extremely slow. While there is now wi-fi access, this is an individualised solution to the more general problem of limited electronic communication at the university, since it requires each student to have his or her PC, tablet or smart phone.

Staff housing is either not available or inadequate, with little security and many residents having only filial connections with the university. When AusAID collaborating with the Group of Eight Australian (Go8) universities made a short-term appointment to assist the Politics Science strand, the person was required to stay in an up-market hotel which in turn severely depleted the resources available for improving teaching. The Papua New Guinea Development Strategic Plan 2010-2030 stated that in 2008, two years prior to the Garnaut-Namaliu Report, the total capacity of all six universities was 10,365 enrolled students with 3135 graduates (Government of Papua New Guinea, 2010 (a), p. 60). As noted above, by 2013 USP-serving a population one third of PNG's - enrolled about two and a half times the numbers studying at these six universities.

At the same time as the Garnaut-Namaliu Report was being prepared, the peak state body responsible for national planning could set the goal of developing 'the higher skills necessary for PNG prosperity with a world class tertiary education sector' (Government of Papua New Guinea, 2010 (a), p. 59). While aware of the already considerable and increasing pressure for tertiary 


\section{‘FAILED’ STATES AND THE ENVIRONMENT}

education being generated throughout the country, the Universities Review's authors sought to dampen expectations of any rapid expansion in university education, proposing only to 'limit expansion of State-funded places at State universities to 3-4 per cent per year for the next decade, just above the rate of population growth, while the quality base is being rebuilt' (Garnaut \& Namaliu, 2010, p. 1).

From this brief summary of the current conditions of USP and UPNG, the most obvious question which arises is why, given some important similarities in the starting points for both institutions, has the massive disparity occurred? The final section of the paper provides a partial answer to the question, focusing particularly on the part that foreign aid, monetary and advisory, has played in the outcomes.

\section{Good and bad aid: Internationalism and reactionary ruralism}

According to the Garnaut-Namaliu Report, '(i)n 2009, the inflation-adjusted public funding per student made available to the universities was about one fourteenth of the level in the early years of Independence'. While there had been more general substantial reductions in public expenditure which affected all the core services provided by government the cuts 'went much further with higher education than in other areas'. For the economist and the former politician, now consultant advisers, this slashing 'went too far' even if '(s)ome downward adjustment in the share of public resources going to the universities was warranted after the crash programmes preceding Independence' (Garnaut \& Namaliu, 2010, p. 8).

'Warranted' is of course an assessment and justification after the event and does not explain why the massive reduction occurred. To understand fully how UPNG has come to the current abysmal condition would require a more substantial examination than is possible here. Nevertheless some major factors can be identified, including the part which international advice to successive Papua New Guinea governments has contributed.

When Australian budget and programme aid was so important for the initial establishment of UPNG, why this flow of funds ceased after Independence is the appropriate starting point for the explanation. During the negotiations for the move to self-government and Independence, the process through which Australian aid was provided to PNG changed. Previously 'budget aggregates were handed down from Canberra and there was no mechanism 
in Port Moresby for integrating decisions on these aggregates into wider aspects of decision-making by governments'. This support 'held (the economy) together, and provided (the) main impetus to growth, by extraordinarily large injections of Australia aid which contributed directly 53 percent of public expenditure in 1971/72' (Garnaut, 1981, p. 159). Following lengthy negotiations in Port Moresby and Canberra a post-Independence aid agreement was struck. 'Australian aid was to be provided as untied cash grants, minimum amounts of aid were specified forward for five years' and terms written into the agreement which gave hope that 'clear principles could be agreed upon for upward adjustment of aid levels above specified minima' (Garnaut, 1981, pp. 178). However subsequently Australian aid would provide a decreasing proportion of the national budget as other international as well as domestic sources of revenue grew. That aid would also change, from untied budget support to project, program and other closely supervised forms of aid.

While the transfer of principal responsibility for aid expenditure decisions to the newly constructed institutions of PNG satisfied anti-colonial nationalist sentiments in both countries (Whitlam, 1985, pp. 71-101), outcomes now were more dependent upon the turns and twists in the domestic political economy. Initially the Minister for Finance, (Sir) Julius Chan-leader of the small but influential People's Progress Party-was able to support a 'new policy of financial stringency'. Garnaut claims that, despite early opposition to the direction of government policy, an 'atmosphere developed within which it was nationalist Papua New Guinean behaviour not to spend money...This reduction in expectations was necessary to economic stability and to political stability, and can be counted as one of the major successes of the early years of national government in Papua New Guinea' (Garnaut, 1981, pp. 178-179).

Garnaut's account of stringency needs to be tempered by a recognition that there were more important changes taking place in the national political economy. These changes gave rise to the immediate post-independence criticism of four senior bureaucrats, the so-called 'gang of four' which included Namaliu that there was rising corruption in the country. As much as budgetary restraint was a feature of the transitional years, so too was the flood of money that washed through PNG.

The indigenisation of the public administration which was largely completed in the years immediately after Independence played an important part in joining the politics and economics of accumulation. During most of the 
colonial period, public servants were barred from linking their state employment with private accumulation. As Independence approached these barriers became less enforceable, especially when expatriates entered into joint ventures with Papua New Guineans. After self-government the remaining walls tumbled down. Straddling between state employment and ownership of commercial enterprises became commonplace. The formation of provincial governments increased the arenas in which business activity was coupled with holding public office. Joining public employment and commercial ownership made more conspicuous how political leverage was exercised by state officials seeking to advance their accumulation. Criticism of what was regarded as corruption was constant. Holding government office and asserting parliamentary authority became all-important, as the rapid increase in the numbers of people contesting seats at national elections suggested.

By the mid-1980s, the indigenous takeover of many areas of commerce was completed. This included moves into nearly all the coffee plantations, most of the copra and cocoa plantations as well as associated activities in transportation and processing (MacWilliam, 1993). Initial attempts to expand into import substituting industries were nevertheless stymied by a combination of government opposition and academic advisers. Instead the indigenous bourgeoisie had begun to look overseas, a direction which accelerated substantially over the next twenty years. The commercial shift meant less and less concern for domestic development, which coincided with the international movement that emphasised reductions in state expenditure, lower tax regimes and privatisation. The indigenous wealthy followed their late colonial predecessors but in a more extensive manner to send their children overseas for education.at all levels. Salaried and skilled so-called middle class workers now also send their children overseas, including for tertiary education in the Philippines.

The revolt on Bougainville which escalated in 1988 and subsequently closed the Panguna mine forced a major reduction in government revenues and some areas of expenditure, including for education and health, but not for the PNG defence forces (May \& Spriggs, 1990; Spriggs \& Denoon, 1992; Regan \& Griffin, 2005). The full consequences of these drastic reductions, carried out in the name of balancing the budget and coming on top of the earlier 'trimming', would become apparent over subsequent decades as the universities were unable to produce the skilled and managerial labour required when the economy expanded again in the early twenty first century. When 
this occurred, as had happened in the 1960s, growth required major imports of labour. As the Garnaut-Namaliu Report noted:

\begin{abstract}
Recent analysis suggests that expenditure on foreign personnel alone amounts to over three quarters of a billion kina per annum, or about three and a half percent of GDP. This is unusual. The social as well as private rate of return on good, high-level education is extremely high, even if we calculate only the financial value of replacement of imported personnel. The social rate of return on the skills and capacities necessary for good governance is higher still, by a wide margin. (Garnaut \& Namaliu, p. 11)
\end{abstract}

The 2010-2030 PNG Development Strategic Plan makes a similar point and directly relates the drain to the state of the country's tertiary education institutions, claiming that: 'Inadequate higher education has resulted in one third of skilled jobs being held by foreigners who drain K780 million out of PNG' (Government of Papua New Guinea, 2010 (a), p. 60).

So far the analysis appears to have ignored policy regarding the bulk of the country's population. In PNG, more than 80 percent of the people live in the countryside, outside major urban centres, on smallholdings and in small villages. This existence is usually characterised as living subsistence lifestyles, a description which is unchanging even as commercialisation has extended to all areas and people. Again to cite the Universities Review: 'There has been a vast expansion of monetised exchange of food among other things' (Garnaut \& Namaliu 2010, p. 7). It is now necessary to bring 'village life' into the analysis of post-Independence government policy for higher education. As will be shown, there remains a pronounced 'rural bias' in education policy, which has international and domestic roots.

\title{
Reactionary ruralism
}

A central theme in post-war colonial education policy, as already noted, was the need to develop primary education which provided the skills necessary to raise standards of living for the bulk of the population through increased smallholder agricultural production. During the 1950s small holdings and village life were secured in order to raise agricultural production and productivity as the precursor for an industrial, urban existence and independent country. As the relevant Australian Minister Paul Hasluck explained, a major 
purpose of colonial policy under an agrarian doctrine of development was to secure village life before the uncertainties and vicissitudes of urban existence, proletarian life, took over (Wright, 2002; MacWilliam, 2013).

While by the late 1950s and early 1960s there was international and domestic pressure to rapidly expand secondary and tertiary schooling, even before Independence there had started to be opposition to the focus on more expensive 'elite' education. Missing from consideration was that further improvements in primary education required more, not fewer, university graduates, an absence which became especially noticeable in the re-emphasis upon primary education of the 1980s and 1990s. The necessary reciprocal relationship between primary, secondary and tertiary education still receives little policy attention in PNG even as parents become more and more indebted in the drive to ensure their children can go to university.

This re-emphasis upon giving priority to primary education was fuelled in part by the beginning of cuts to most forms of public expenditure and became part of the contest over declining relative shares. The post-Independence cuts to expenditure drastically affected not just university education, as noted above, but also primary and secondary education. Even as smallholder production became relatively more important and plantation production less so in key export crops, including coffee and cocoa, the critical developmental role of the late colonial state ceased to exist (MacWilliam, 2013). Stabilisation funds, initially intended to smooth out price fluctuations on international markets and maintain price incentives to keep smallholders increasing production, became, instead, welfare payments. In the words of one agricultural adviser, payments from the funds to smallholders for marketed produce became 'just like working for the dole' (MacWilliam, 1996).

As is shown below, it was at this critical point in PNG's post-colonial development that international advice became crucial for the decline of UPNG. As education planning became more emphatically opposed to tertiary education, the advice reinforced not just the drive to cut state expenditure in the name of balancing budgets but also pushing for wage cuts (Levantis, 2000). Critics, including the late Tim Curtin, attacked the downplaying of links between tertiary, secondary and primary education while also ignoring the possible budgetary benefits of tertiary educated and higher paid workers. Nevertheless the critics' objections had little effect. Reactionary ruralism became more politically influential, including in World Bank, AusAID and other international forms of advice. 


\section{Primary education first, the rest nowhere}

This political-ideological theme, which emphasised the primacy of state policy directed at supporting rural existence, had three main drivers. Firstly, the conservative objections to the destruction of rural life were given fresh impetus by the late 1960s and early 1970s appearance of unemployment and disorder. Academic defenders of urbanisation as a desirable trend were clearly in a minority (cf. Ward, M., 1970; Ward, R.G., 1970; Conroy 1974). The appearance of urban slums with their attendant poverty disturbed indigenous politicians (Somare, 1975, p. 82). Rural life as an 'asset' was the predominant reactionary view at a moment of major economic and political change.

Secondly, and following from the first, the opposition to industrialisation and the development of manufacturing industries or 'taking the first world route' gained strength. Import substituting industrialisation and even other forms of manufacturing, such as processing agricultural crops beyond preparing fruit for international transportation, were ruled out. Thirdly, the antipathy to urbanisation and industrialisation in turn led to an attempt to press the surplus population back upon the land, in the countryside, even as political power was being transferred to indigenes for whom rural accumulation held out limited, short-term prospects. The effects of reactionary ruralism on policy for tertiary education in general, and UPNG in particular, would become especially severe as the view gained primacy in international and domestic circles over the next three decades.

Even as UPNG was first established and then enlarged, the 'primary education first and foremost' proponents had remained prominent domestically. In 1974, one year before Independence, a committee chaired by the then Director of Education Alkan Tololo produced a report recommending a five year plan which would supposedly reverse the thrust of late colonial policy that included the construction of UPNG. The Tololo Report had little immediate importance except as an indicator of the direction which was then becoming popular, focusing upon community education, primary and secondary schooling and use of vernaculars. The first national Tok Pisin newspaper, Wantok was established in 1970 (Cass, 2014).

From the mid-1980s, the return to the basics of primary education direction became more pronounced. Another Director of Education (Sir) Paulius Matane headed an inquiry which produced a report titled 'A Philosophy of Education'. This document made clear the rural, primary schooling bias which 
should underpin education policy. It also served as a focal point for attacks on the relative privilege of tertiary education. Recommendation 8 proposed that: 'Funds be redirected from Higher Education towards the goal of Universal Primary Education' (Government of Papua New Guinea, 2002, p. 8). By implication, tertiary education was not an essential component of either primary or secondary education.

By the late 1980s, international advice increasingly supported this policy direction, as the reduction in state expenditure for all public education continued (World Bank, 1987; World Bank, 1988). In 1994, the Department of Education produced a National Plan of Action under the slogan 'Education for All' to cover the period from 1994 to 2010. It was developed by a large group of domestic and international officials from the Department of Education, officers of 20 Provincial Education Boards and UNESCO's Principal Regional Office, Asia Pacific. Funds for the Plan were provided by UNESCO and UNICEF. The Plan is introduced by the Minister's 'Forward [sic]'. In the Executive Summary, part 4 'Development Programme' the underlying purpose of education for the most important education ministry is summarised in these terms:

Education will enable students to apply skills and knowledge in their communities and take advantage of traditional work and opportunities for community-based employment. They will not have to move to urban environments in order to find work and will not be inclined to join youth gangs and become criminals because of lack of employment. (Government of Papua New Guinea, 1994, p. xix)

Gangs and criminality were by implication an urban and not also a rural phenomenon. Three years later, the PNG government endorsed the country's first National Education Plan to cover the decade from 1995 to 2004. Constructed through the Department of Education under the 1995 theme of 'Doing More with Less and Doing it Better' the Plan does not include university education, the responsibility of another department. However it notes the necessary connection with universities, pointing out that the '(s)upply of secondary teachers by the university sector is out of step with national need.' The Plan draws upon National Objective 24 for its legitimacy, which states the need to 'develop a schooling system to meet the needs of Papua New Guinea and its people which provides appropriately for the return of children to the 
community for formal employment and for continuation to further education or training.' Community here is synonymous with village life and rural areas. To ensure that the rural direction was not misunderstood, a later section headed 'The Developmental Framework' extended the fear of urbanisation in more detail (Government of PNG, 1998, p.23; see also the Government of Papua New Guinea, 2002).

In none of these plans or reports does the need for a strong and growing university component of the education system appear. That UPNG was at the same time withering and falling into almost irreparable disrepair, and clearly had no place in either domestic or international concerns about education in the country. While USP focused on producing more and more graduates for domestic and international markets for skilled and managerial labour, UPNG indeed did less with less and became much, much worse. Even the few successful areas of the university which received external support and were able to produce graduates able to find international jobs, such as geologists, did not seem to suggest the need to expand rather than contract government and private sector support for UPNG as a whole.

That urban existence and manufacturing industry remains a low, even absent priority in the objectives of university education is clear also in the 2010 Garnaut-Namaliu Review. While briefly noting the role of tertiary education for a democratic polity and for governance, the Review focuses heavily on the priorities for primarily rural activities. It commences from a view of the future of the PNG economy which emphasises that:

The current Southern Highlands-Port Moresby investment is likely to be the tip of the iceberg, as work proceeds on other petroleum and metallic mining, and projects based on Papua New Guinea's renewable energy, and the country's vast potential for sustainable development of forestry, fisheries, agriculture and tourism. (Garnaut \& Namaliu, 2010, p. 9)

While tertiary education is not providing the skills necessary for the mining industry, welfare services, including health and education, there is also an 'excess of demand for all of the skills required by the expansion of the non-renewable resources sector (which) is more acute now than ever before, and will grow wider in the period ahead' (Garnaut \& Namaliu, 2010, p. 10). Although the Review's authors acknowledge that there is a need to meet the 'immense backlog in investment in the range of high-level skills required 
for leadership of institutions in the public sector and civil society as well as business', the possibility that such people may only want to live in urban centres rather than rural areas with few services and widespread disorder does not appear to be of importance in rebuilding PNG's public universities (Garnaut \& Namaliu, 2010, p. 11). As much as the Review constructs a need for university educated personnel, there is never any doubt that it is to the countryside where the bulk of the population lives that the principal attention is to be paid. Manufacturing appears only once, and as a word in a list; there is no consideration given to the role of tertiary education in urbanisation and urban industrialisation.

The rural bias which appears in the Review is also central to the National Higher Education Plan 2010-2040. Planning is for a Papua New Guinea which 'remains an agrarian society with no surplus in producing and trading culture and does not operate in the competitive culture of the exchange economy'. The country has a '(s)mall industrial capacity to create wealth to supplement human labour' (Government of Papua New Guinea, 2010b, Summary, p. 2). Furthermore, there is no intention to change this direction: 'Economic growth will emphasise biodiversity and rural development in alliance with industry and government' (Government of Papua New Guinea 2010b, Summary, p. 7).

\section{Conclusion}

As far as tertiary education policy for PNG is concerned, the long-term international shift of humans to urban centres for employment in manufacturing and service industries is to be ignored. Paradoxically other national and international aid institutions, which might be expected to understand the implications of these important global changes, have instead supported this reactionary direction. The media and popular opinion in PNG, which is usually quick to pick up on 'foreign interference' as evidence of neo-colonial ambitions by foreign powers, has not been critical of the alignment between domestic policy and international institutional advice. Opinion leaders in the country, at least those who appear regularly in the wide range of media which now exists in PNG, seem content with policy which keeps the bulk of people impoverished rural dwellers while, as an educated elite, they enjoy international standards of living, including tertiary education.

At the same time, USP has been provided with substantial international monetary and advisory aid to the point where its Vice-Chancellor can advocate an expanded role for the university in increasing the proportion of the 
population from member countries which enrols in universities, specifically that institution. USP is to have an even more important role in training skilled workers and others for employment within the region and for international markets. Some of these students come from PNG to study for higher degrees which are not available in their home country: USP is in the throes of taking an increased number of Papua New Guineans into its MBA programme, to cite just one example.

As UPNG and other state tertiary institutions have declined in the quality of education provided, there have been attempts - including through international aid - to shift the focus to private universities, including Divine Word established in the late 1970s. However these remain small and there is no evidence that the academic standards are much, if at all, better than exist at UPNG. Instead as pressure for tertiary education increases among the PNG population, more and more undergraduate and graduate ambitions are satisfied by parents sending their children overseas. Unsurprisingly, once educated in the major urban centres of industrial countries, university graduates are not rushing to return to PNG to live in either rural areas or poorly serviced, high crime rate towns and cities.

If the likelihood that tertiary trained people from PNG and other South Pacific countries will emigrate to other locations is increasingly similar, perhaps there is no case for substantial universities in the countries of the region at all. In a perverse manner, this proposition is not entirely dissimilar to what was argued by some expatriates in PNG when the establishment of UPNG was first mooted. 'Why educate bush kanakas' was then, rightly, regarded as deeply racist as well as a barrier to the country's development. Is advocating policies to provide a limited amount of tertiary education to fit Papua New Guineans for an impoverished rural existence not offensive now and also very bad aid?

\section{References}

Anderson, D. (1977). An economic survey of smallholder coffee producers-1976. Port Moresby: Department of Primary Industry, Planning Economics Marketing Branch. AusAID (2006). Pacific 2020: Challenges and opportunities for growth. Canberra: Commonwealth of Australia.

Cass, P. (2014). Press, politics and people in Papua New Guinea 1950-1975. Auckland: Unitec e-press.

Commonwealth of Australia (2011). Independent Review of Aid Effectiveness. Canberra: AusAID. 


\section{'FAILED’ STATES AND THE ENVIRONMENT}

Conroy, J.D. (1974). Urbanisation in Papua New Guinea: a development constraint. In May, R.J. (Ed.), Priorities in Melanesian development (pp. 59-70). Canberra and Port Moresby: Sixth Waigani Seminar, RSPAS, ANU.

Conroy, J. (1976). Education, employment and migration in Papua New Guinea. Monograph no.3. Canberra: Development Studies Centre, ANU.

Cowen, M.P. \& Shenton, R.W. (1996). Doctrines of development London: Routledge.

Garnaut, R. (1981). The framework of economic policy-making. In J.A.Ballard (ed.), Policy-making in a new state: Papua New Guinea 1972-77. St. Lucia: Queensland University Press.

Garnaut, R. \& Namaliu, Sir R. (2010). PNG universities review report to prime ministers Somare and Rudd, May. Retrieved on April 30, 2014, from: www.rossgarnaut. com.au/Documents/PNGUniversitiesReview310510v7.pdf

Government of Papua New Guinea (1973). Report of the committee investigating tribal fighting in the Highlands. Port Moresby: Government Printer.

Government of Papua New Guinea (1994). National plan of action 1994-2010. Port Moresby: Department of Education.

Government of Papua New Guinea (1998). National education plan. Port Moresby: Department of Education.

Government of Papua New Guinea (2002). The state of education in Papua New Guinea 2002. Port Moresby: National Department of Education, Education Reform Facilitating and Monitoring Unit.

Government of Papua New Guinea (2010a). Papua New Guinea development strategic plan 2010-2030. Port Moresby: Papua New Guinea Department of National Planning and Monitoring.

Government of Papua New Guinea (2010b). Papua New Guinea National Higher Education Plan III 2010-2040. Port Moresby: Papua New Guinea Council for Higher Education.

Larmour, P. (Ed.) (1998). Governance and reform in the South Pacific. Canberra: National Centre for Development Studies, ANU.

Levantis, T. (2000). Papua New Guinea: employment wages and economic development. Canberra and Port Moresby: Asia Pacific Press, ANU, and Institute of National Affairs.

MacWilliam, S. (1986). International capital, indigenous accumulation and the state in Papua New Guinea: the case of the Development Bank. Capital and Class No. 29, Summer, pp. 150-181.

MacWilliam, S. (1993). The politics of privatization: The Case of the Coffee Industry Corporation in Papua New Guinea. Australian Journal of Political Science, 28(3), 481-498.

MacWilliam, S. (1996). 'Just like working for the dole': Export crops, rural households and state subsidies in Papua New Guinea. The Journal of Peasant Studies, 23(4), 40-78.

MacWilliam, S. (2002). Poverty, corruption and governance in Fiji. Pacific Economic Bulletin, 17(2), 138-145. 
MacWilliam, S. (2013). Securing village life: Development in late colonial Papua New Guinea. Canberra: ANU E-Press.

May, R.J. (1998). From promise to crisis: a political economy of Papua New Guinea. In Larmour, (Ed.), Governance and reform in the South Pacific (pp. 54-73).

May, R.J., and Spriggs, M. (Eds.) (1990). The Bougainville crisis. Bathurst: The Crawford House Press.

Ratuva, S. (2013). The politics of preferential development: Trans-global study of affirmative action and ethnic conflict in Fiji, Malaysia and South Africa. Canberra: ANU E-press.

Regan, A. J., \& Griffin, H. M. (Eds.) (2005). Bougainville before the conflict. Canberra: RSPAS, Pandanus Books.

Riddell, R. C. (2014). Does foreign aid really work? An updated assessment. Discussion Paper 33. Canberra: Development Policy Centre, ANU.

Robie, D. (1999). Pacific newsrooms and the campus: Some comparisons between Fiji and Papua New Guinea. Australian Studies in Journalism 8: 176-196.

Robie,D. (2004). Mekim Nuis:South Pacific Media, Politics and Education Suva: University of the South Pacific Book Centre.

Smith, P. (1985). Colonial policy, education and social stratification, 1945-75. In Bray, M. \& Smith, P. (Eds.) Education and social stratification in Papua New Guinea. Melbourne: Longman Cheshire.

Somare, (Sir) M. T. (1975). Sana. Port Moresby: Nuigini Press.

Spriggs, M. \& Denoon, D. (Eds.) (1992). The Bougainville crisis: 1991 Update. Political and Social Change Monograph 16 Bathurst: Department of Political and Social Change, RSPAS, ANU in association with Crawford House Press.

Thompson, H. \& MacWilliam, S. (1992). The political economy of Papua New Guinea: Critical essays. Manila and Wollongong: Journal of Contemporary Asia Publishers.

University of Papua New Guinea (1986). The University of Papua New Guinea 19661986. Port Moresby: UPNG, New Guinea Collection, University Library.

University of Papua New Guinea (2010). Political science curriculum revision 2010. Unpublished Paper.

University of the South Pacific (2010). Strategic plan 2010-2012. Laucala: USP.

University of the South Pacific (2013). Strategic plan 2013-2018. Laucala: USP.

Ward, M. (1970). Urbanisation - threat or promise? New Guinea, 5(1), 57-62;

Ward, R.G. (1971). Internal migration and urbanisation in Papua New Guinea. In Research Bulletin No.42. Population growth and Socio-Economic Change. Papers from the second demography seminar Port Moresby (1970). Canberra and Boroko: New Guinea Research Unit, ANU:.81-107. Reprinted in May, R.J. (Ed.) (1977). Change and Movement: readings on Internal Migration in Papua New Guinea Canberra: PNG IASER in association with ANU Press:27-51.

Whitlam, G. (1985). The Whitlam government 1972-1975. Ringwood, Victoria: Penguin Books.

Wilson, L.D. \& Evans, G.B.A. (1975). Sample survey of smallholder coffee producers. Port Moresby: Department of Agriculture, Stock and Fisheries Rural Economics and Commodity Marketing Branch. 


\section{'FAILED’ STATES AND THE ENVIRONMENT}

World Bank (1987). Costs and financing of education in Papua New Guinea. Washington: IBRD.

World Bank (1988). Papua New Guinea: Policies and prospects for sustained and broad-based growth. Washington: IBRD.

Wright, H. (2002). A liberal 'respect for small property': Paul Hasluck and the 'landless proletariat' in the territory of Papua and New Guinea, 1951-63. Australian Historical Studies, 33(119), 55-72.

Dr Scott MacWilliam became a visiting fellow in the State Society and Governance in Melanesia Program at The Australian National University's College of Asia and the Pacific from July 2012. Previously he lectured in the Department of Management at the Western Australian Institute of Technology, in the School of Social Sciences at Curtin University of Technology, the Department of Political and Administrative Studies at the University of Papua New Guinea, and the Department of History and Politics at the University of the South Pacific. At USP, where he was associate professor, Dr MacWilliam established the undergraduate governance programme. After leaving USP, he taught for more than ten years in the Policy and Governance program in the National Centre for Development Studies, subsequently the Crawford School at ANU. scottmac69@grapevine.com.au 